Article

\title{
Prevalence of Asthma and COPD and Blood Eosinophil Count in a Middle-Aged Belgian Population
}

\author{
Sara R. A. Wijnant ${ }^{1,2}(0)$, Lies Lahousse ${ }^{2}(0)$, Marc L. De Buyzere ${ }^{3}$, Guy G. Brusselle ${ }^{4}$ and \\ Ernst R. Rietzschel ${ }^{5, *}$ \\ 1 Department of Respiratory Medicine, Ghent University Hospital, Corneel Heymanslaan 10, \\ 9000 Ghent, Belgium \\ 2 Department of Bioanalysis, Faculty of Pharmaceutical Sciences, Ghent University, Ottergemsesteenweg 460, \\ 9000 Ghent, Belgium \\ 3 Department of Cardiology, Ghent University Hospital, and Ghent University, Corneel Heymanslaan 10, \\ 9000 Ghent, Belgium \\ 4 Department of Respiratory Medicine, Ghent University Hospital, and Ghent University, Corneel \\ Heymanslaan 10, 9000 Ghent, Belgium \\ 5 Department of Cardiology and Biobanking and Cardiovascular Epidemiology, Ghent University Hospital \\ and Ghent University, Corneel Heymanslaan 10, 9000 Ghent, Belgium \\ * Correspondence: Ernst.Rietzschel@UGent.be
}

Received: 17 June 2019; Accepted: 25 July 2019; Published: 28 July 2019

\begin{abstract}
Various phenotypes exist in asthma and Chronic Obstructive Pulmonary Disease (COPD). These are important to identify in order to guide treatment decisions. We aim to investigate the prevalence and clinical characteristics of obstructive airway diseases in the middle-aged population. We estimated the prevalence of COPD and/or asthma in the Asklepios cohort study (Belgium), using information from the third European Community Respiratory Health Survey (ECRHS3), medical records, and spirometry. Respiratory symptoms, respiratory medication, and current disease status distinguished clinical from sub-clinical cases. In addition, we compared the blood eosinophil count $/ \mu \mathrm{L}$ (median [IQR]) between cases and controls. Of the 2221 participants (mean age $56.1 \pm 5.9$ years; $48.7 \%$ males), 138 (6.2\%) participants had clinical current asthma, $22(1.0 \%)$ participants had sub-clinical ever asthma, 102 (4.6\%) had sub-clinical spirometry-defined COPD, $104(4.6 \%)$ participants had clinical spirometry-confirmed COPD, and $11(0.5 \%)$ had asthma and COPD overlap (ACO). Clinical current asthma (160.0 [110.0-250.0]), sub-clinical ever asthma (170.0 [110.0-230.0]), and clinical COPD (160.0 [110.0-220.0])—but less sub-clinical COPD (140.0 [90.0-210.0])—had higher eosinophil counts, compared to controls (130.0 [80.0-200.0]). We conclude that obstructive airway diseases are prevalent in the middle-aged Asklepios cohort. Moreover, the systemic eosinophil count is increased in clinical COPD cases, and in asthma cases regardless of clinical remission.
\end{abstract}

Keywords: asthma; chronic obstructive pulmonary disease; eosinophils; middle aged; prevalence; epidemiology

\section{Introduction}

Obstructive pulmonary diseases have been widely studied, with over 300 million people worldwide affected by both asthma and Chronic Obstructive Pulmonary Disease (COPD) [1-6]. Given their increasing burden and financial impact [7-9], more attention is rising for the late-onset asthma phenotype [10], that differs from early-onset asthma with respect to genetic susceptibility, environmental exposures, pathogenic mechanisms, comorbidities, prognosis and treatment response [10-14]. 
Evidence is emerging that, besides tobacco smoking, risk factors, such as respiratory infections, poor nutritional status, chronic asthma, impaired lung growth, poor socio-economic status and genetic factors are also important for COPD development [1]. Moreover, despite the multitude of treatments and interventions available to patients with chronic respiratory diseases, many patients remain refractory, while those who do respond, show marked treatment response variability [15]. Various phenotypes exist in both asthma and COPD, and these are important to recognize, in order to guide treatment decisions.

In asthma, type 2 helper T-cell (Th2)-mediated eosinophilic airway inflammation is typical, whereas in COPD, type 1 helper T-cell (Th1)-mediated neutrophilic inflammation predominates. In each condition, however, a spectrum of phenotypes exists [15]. Blood eosinophil count has been associated with a COPD phenotype, that is at higher risk for frequent exacerbations, but with better corticoid responsiveness [16]. Elevated blood eosinophil count is a marker of active asthma [17-24], and few studies, with clinically remitted asthma subjects, showed an association between persistent eosinophilia and persistent asymptomatic airway hyper-responsiveness (AHR) [25-27]. Given that persistent AHR could be a risk factors for relapse [28], the measurement of persistent eosinophilic inflammation, as a proxy of persistent AHR in a more representative sample of the general population, is warranted. Therefore, the objective of this study is to investigate the prevalence and clinical characteristics of obstructive airway diseases in middle-aged participants of the Asklepios Study, a community-based cohort study in Belgium.

\section{Experimental Section}

Subjects were chosen from the Asklepios Study, a random sample of participants recruited from the general population with the approval of the ethics committee of Ghent University Hospital, and in accordance with the Declaration of Helsinki (see Appendix A for a more detailed description) [29]. This study uses measurements from round 2 of the study (2011-2016) as no spirometry was performed in round 1 (2002-2004). All participants gave written informed consent.

A single trained examinator performed spirometry in all subjects according to the American Thoracic Society/European Respiratory Society (ATS/ERS) guidelines, using a portable spirometer (Spirobank G; MIR; Rome, Italy). Forced Expiratory Volume in $1 \mathrm{~s}$ (FEV1), Forced Vital Capacity (FVC), FEV1/FVC, the spirogram (volume-time curve) and maximal expiratory flow-volume curves were measured. Spirometry results that did not meet the ATS/ERS criteria for acceptability and reproducibility were classified as non-interpretable. Percent predicted of FEV1 and FVC were calculated using GLI reference equations [30]. The interpretation of all spirometry results was carried out by an experienced researcher (LL), and in case of disagreement with the computerized interpretation, using the assistance of a respiratory physician (GB).

Case finding by three researchers (SW, LL and ER) bundled all the participants with either, respiratory symptoms (question 1-9 from the third European Community Respiratory Health Survey ECRHS3 question 1-9; see Appendix B), a history of asthma or COPD (general practitioner's [GP] medical file or ECRHS3), respiratory medication usage (GP medical file or ECRHS3), or an obstructive pulmonary function test (FEV1/FVC < 0.7). We relabeled 24 cases-that were labelled by the GP as COPD—as asthma because their FEV1/FVC ratio was 0.7 or higher (mean FEV1/FVC $0.77 \pm 0.42$ ).

Clinical asthma cases were distinguished from sub-clinical asthma cases when participants with asthma (a history of asthma in the GP medical file or ECRHS3 question 12-13) either a. used respiratory medication (GP medical file, or ECRHS3 question 10 or question 19), or b. reported any respiratory symptoms during the past 12 months (ECRHS3 question 1-9), or c. self-reported current asthma (ECRHS3 question 13). Clinical COPD cases were distinguished from sub-clinical COPD cases when participants with COPD (FEV1/FVC < 0.7) either a. used respiratory medication (GP medical file or ECRHS3 question 10 or question 19), or b. reported any respiratory symptoms during the past 12 months (ECRHS3 question 1-9), or c. self-reported known COPD (ECRHS3 question 18). Clinical COPD cases were divided into mild (FEV1 $\geq 80 \%$ ) and moderate to severe COPD (FEV1 $<80 \%$ ). 
Asthma and COPD overlap (ACO) cases had a diagnosis of both asthma and COPD (GP medical file or ECRHS3) in the presence of an obstructive pulmonary function (FEV1/FVC $<0.7)$, and were not included in asthma and COPD groups for analyses.

The normal group (no history of asthma or COPD, nor respiratory symptoms or respiratory medication use and normal spirometry [FEV1/FVC $\geq 0.7$ and FVC $\geq 80 \%]$ ) and the subnormal group (respiratory symptoms or medication use but no diagnosis of asthma or COPD and normal spirometry) were pooled to form the control group. We excluded cases with a spirometry suggestive of restrictive pulmonary disease (FVC $<80 \%$ or based on an abnormal flow-volume curve; $n=15$ ). Subjects with Preserved Ratio Impaired Spirometry (PRISm; and FEV1/FVC $\geq 0.7$ and FEV1 $<80 \% ; n=63$ ) were not excluded.

Respiratory medication (R03) was defined according to The Anatomic Therapeutic Chemical Classification (ATC) System. Blood eosinophil count was measured on EDTA whole blood using an ISO 17,025 Beltest accreditation in a reference laboratory (Laboratorium Klinische Biologie, UZ Ghent; ISO 9002; NBN EN 45001). We compared smoking history (pack-years as years times daily cigarettes divided by 20), arterial hypertension (systolic blood pressure $\geq 140 \mathrm{mmHg}$, diastolic blood pressure $\geq 90 \mathrm{mmHg}$ or use of anti-hypertensive medication), body composition (overweight: Body Mass Index $[\mathrm{BMI}] \geq 25 \mathrm{~kg} / \mathrm{m}^{2}$; obesitas: BMI $\geq 30 \mathrm{~kg} / \mathrm{m}^{2}$ ), type 2 diabetes (fasting blood glucose $\geq 126 \mathrm{mg} / \mathrm{dL}$ or use of blood glucose lowering medication), renal function impairment (mild: estimated glomerular filtration rate [eGFR, using the CKD-EPI equations ] $<90 \mathrm{~mL} / \mathrm{min} / 1.73 \mathrm{~m}^{2}$; moderate to severe: eGFR $<60 \mathrm{~mL} / \mathrm{min} / 1.73 \mathrm{~m}^{2}$ ), and atopy (self-reported allergic rhinitis or hay fever [ECRHS3 question 11] or use of anti-allergic medications [ATC R06]) between cases and controls.

Prevalence was calculated by dividing the total number of cases by the total number of participants. Data are expressed as mean \pm standard deviation (SD) for normally distributed variables or as median (interquartile range [IQR]) for non-normally distributed variables. We compared basic characteristics between groups with the Student's $t$-test for continuous parametrical variables, the Mann-Whitney-U test for continuous non-parametrical variables, or the Chi-square/Fisher exact test for categorical variables. Odds ratios (OR) from logistic regression analyses were adjusted for age, sex, BMI, pack-years and eosinophil percentage. Possible confounders were chosen based on univariate testing and literature data. All statistical analyses were carried out using SPSS version 25 (IBM, New York, NY, USA) and R version 3.5.1 (R Project for Statistical computing, Vienna). A $p$-value $<0.05$ was considered statistically significant. The data supporting the findings of this study are only available from the principal investigator of the Asklepios Study upon reasonable request and after positive evaluation by the Asklepios Steering Committee.

\section{Results}

Of 2221 participants with lung function measurements (mean age $56.1 \pm 5.9$ years, $48.7 \%$ males), $377 \mathrm{had}$ asthma and/or COPD (Figure 1). Of 160 asthma cases (prevalence $7.2 \% ; 6.8 \%$ in males and $7.5 \%$ in females), 138 had current asthma ( $45.7 \%$ male) and 22 had sub-clinical asthma ( $50.0 \%$ male). Another eleven cases with asthma had concomitant COPD (i.e. ACO; prevalence $0.5 \%, 54.5 \%$ male). Of 206 COPD cases (prevalence $9.3 \% ; 12.0 \%$ in males and $6.7 \%$ in females, $p<0.001$ ), 104 were clinical cases: 62 with mild COPD (69.4\% male) and 42 with moderate to severe COPD (61.9\% male). 102 subjects had sub-clinical COPD ( $59.8 \%$ male). The prevalence of obstructive spirometry, according to the LLN method, was $6.5 \%$. Of 2166 subjects with interpretable spirometry measures, 63 had PRISm (mean age $56.4 \pm 6.2$ years, $44.4 \%$ male; Figure 2). 


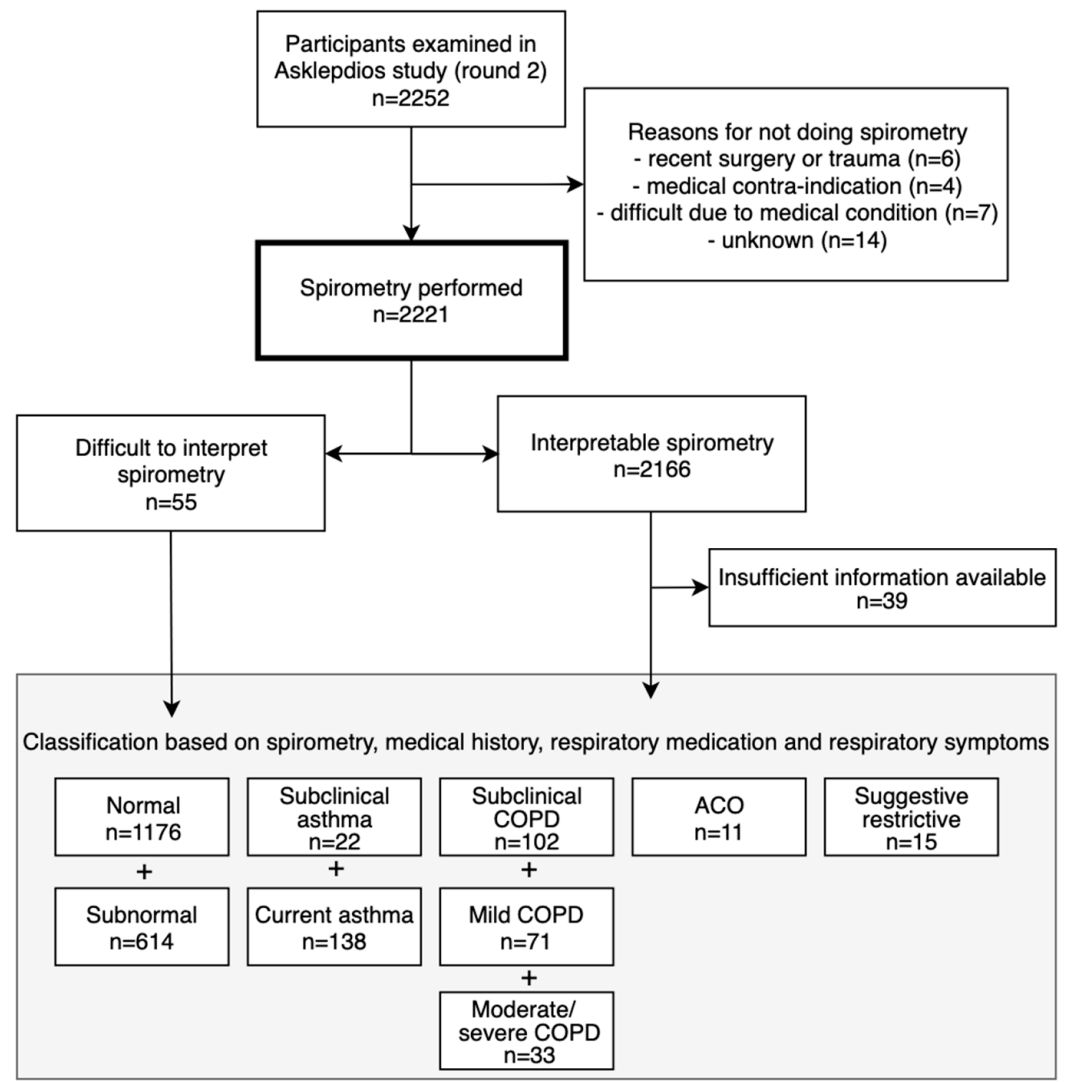

Figure 1. Flowchart of participants.

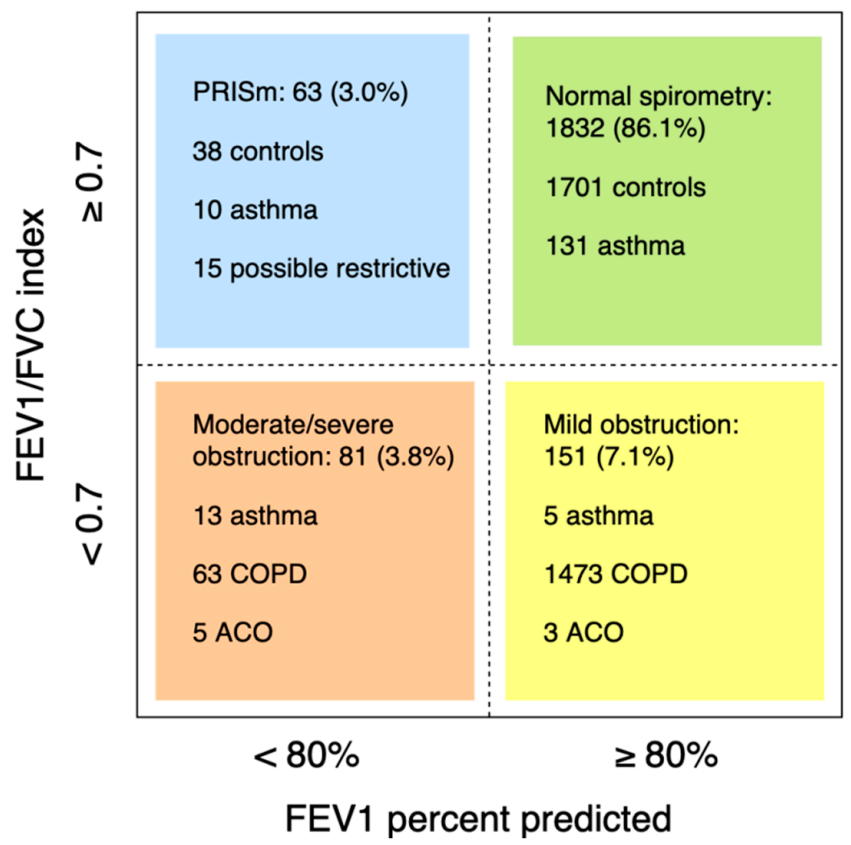

Figure 2. Lung function of subjects with an interpretable spirometry test. Participants with insufficient clinical information, available to categorize in a lung function group, were excluded $(n=39)$.

Table 1 shows the characteristics of controls and cases with asthma and COPD. Smokers showed an increased risk of COPD, starting from 10 pack-years (adjusted OR = 1.8, 95\% CI 1.1-2.8; Figure 3, Figure $\mathrm{S} 1) .40 .4 \%(n=42)$ of clinical COPD cases had smoked 10 pack-years or less. COPD subjects that had smoked 10 pack-years or less were younger (mean age $56.0 \pm 6.0$ years versus $58.7 \pm 4.9, p=0.001$ ) 
and had more often atopy ( $24.7 \%$ versus $12.1 \%, p=0.026$; see Table S1 for other characteristics) than other COPD subjects. Current smokers had a higher risk of asthma compared to never/ex-smokers (adjusted OR $=1.5,95 \%$ CI 0.9-2.6). Of the symptomatic COPD cases, only 31.3\% (30/96) were previously diagnosed with COPD and/or received respiratory treatment, in contrast to $99.1 \%(116 / 117)$ of symptomatic asthma cases (Figure S2).

Table 1. Baseline characteristics of subjects in the Asklepios Study.

\begin{tabular}{|c|c|c|c|}
\hline Subject Characteristics & $\begin{array}{l}\text { Control Subjects } \\
\quad(n=1790)\end{array}$ & $\begin{array}{l}\text { Asthma } \\
(n=160)\end{array}$ & $\begin{array}{c}\text { COPD } \\
(n=206)\end{array}$ \\
\hline Age (year) & $56.0 \pm 5.9$ & $55.2 \pm 6.2$ & $57.3 \pm 5.7 *$ \\
\hline Male (\%) & $841(47.0 \%)$ & $74(46.3 \%)$ & $130(63.1 \%) *$ \\
\hline Higher education & $685(38.5 \%)$ & $55(34.6 \%)$ & $79(38.7 \%)$ \\
\hline Pack-years nicotine (year) & $0.0(0.0-7.5)$ & $0.0(0.0-6.5)$ & $8.8(0.0-27.0)$ * \\
\hline Former smoker & $650(36.3 \%)$ & $60(37.2 \%)$ & $71(34.5 \%)$ \\
\hline Current smoker & $152(8.5 \%)$ & $19(11.9 \%)$ & $59(28.6 \%) *$ \\
\hline \multicolumn{4}{|l|}{ Cardiovascular risk factors } \\
\hline Systolic blood pressure (mmHg) & $130.2 \pm 15.1$ & $129.7 \pm 13.3$ & $129.4 \pm 14.9$ \\
\hline Diastolic blood pressure (mmHg) & $81.6 \pm 9.9$ & $82.1 \pm 9.6$ & $80.2 \pm 10.1 *$ \\
\hline BMI $\left(\mathrm{kg} / \mathrm{m}^{2}\right)$ & $26.8 \pm 4.5$ & $27.9 \pm 5.4 *$ & $25.8 \pm 3.9 *$ \\
\hline Total cholesterol (mg/dL) & $209.7 \pm 40.0$ & $209.3 \pm 36.6$ & $204.9 \pm 38.1$ \\
\hline Glycaemia (mg/dL) & $96.6 \pm 16.3$ & $97.2 \pm 16.2$ & $96.4 \pm 13.7$ \\
\hline \multicolumn{4}{|l|}{ Inflammation } \\
\hline High sensitive CRP (mg/L) & $0.99(0.53-2.16)$ & $1.28(0.67-2.66) *$ & $0.91(0.48-1.85)$ \\
\hline White blood cell count $\left(10^{9} / \mathrm{L}\right)$ & $6.7 \pm 1.8$ & $6.8 \pm 1.8$ & $7.1 \pm 2.0 *$ \\
\hline Eosinophil percentage $(\%)$ & $2.0(1.3-3.0)$ & $2.4(1.7-3.8) *$ & $2.3(1.5-3.4)^{*}$ \\
\hline \multicolumn{4}{|l|}{ Lung function } \\
\hline FEV1 percent predicted (\%) & $104.6 \pm 12.9$ & $96.4 \pm 15.9^{*}$ & $87.3 \pm 18.2 *$ \\
\hline FVC percent predicted (\%) & $104.7 \pm 12.9$ & $100.4 \pm 13.8^{*}$ & $105.6 \pm 18.7^{*}$ \\
\hline FEV1/FVC $(\%)$ & $78.9 \pm 4.2$ & $75.8 \pm 6.3 *$ & $64.5 \pm 5.9 *$ \\
\hline Respiratory symptoms in the past 12 months & $603(34.4 \%)$ & $117(73.6 \%) *$ & $96(48.0 \%) *$ \\
\hline \multicolumn{4}{|l|}{ Comorbidities } \\
\hline Arterial hypertension & $781(43.6 \%)$ & $78(48.8 \%)$ & $95(45.9 \%)$ \\
\hline Overweight $\left(\mathrm{BMI} \geq 25\right.$ and $\left.<30 \mathrm{~kg} / \mathrm{m}^{2}\right)$ & $759(42.4 \%)$ & $72(45.0 \%)$ & $85(41.1 \%)$ \\
\hline Obese $\left(\mathrm{BMI} \geq 30 \mathrm{~kg} / \mathrm{m}^{2}\right)$ & $379(21.2 \%)$ & $42(26.3 \%)$ & $23(11.2 \%) *$ \\
\hline Type 2 diabetes & $118(6.6 \%)$ & $14(8.8 \%)$ & $15(7.3 \%)$ \\
\hline Mild renal function impairment (eGFR 60-89) & $1137(63.6 \%)$ & $98(61.3 \%)$ & $132(63.6 \%)$ \\
\hline Moderate to severe renal function impairment $(\mathrm{eGFR}<60)$ & $70(3.9 \%)$ & $9(5.6 \%)$ & $8(3.9 \%)$ \\
\hline Atopy & $278(16.7 \%)$ & $81(53.6 \%) *$ & $35(18.6 \%)$ \\
\hline \multicolumn{4}{|l|}{ Laboratory parameters } \\
\hline eGFR (mL/min/1.73 m²) & $84.9 \pm 17.1$ & $83.5 \pm 16.8$ & $84.9 \pm 16.4$ \\
\hline Creatinine $(\mathrm{mg} / \mathrm{dL})$ & $8.8 \pm 1.7$ & $8.9 \pm 1.8$ & $9.1 \pm 1.7 *$ \\
\hline Microalbuminuria (mg/L) & $6.8(4.4-11.6)$ & $6.3(4.7-10.9)$ & $6.4(4.2-10.3)$ \\
\hline Hematocrit $(\%)$ & $41.5 \pm 3.3$ & $41.7 \pm 3.3$ & $42.2 \pm 3.0 *$ \\
\hline Thrombocytes $\left(10^{9} / \mathrm{L}\right)$ & $242.9 \pm 56.3$ & $249.5 \pm 52.6$ & $246.0 \pm 50.5$ \\
\hline \multicolumn{4}{|l|}{ Respiratory medication } \\
\hline Respiratory medication use & $49(2.7 \%)$ & $100(62.5 \%) *$ & $30(14.6 \%) *$ \\
\hline Self-reported respiratory medication use & $40(2.3 \%)$ & $95(59.7 \%) *$ & $29(14.5 \%) *$ \\
\hline GP reported respiratory medication use (ATC R03): & 19 (1.1\%): & $80(50.0 \%) *:$ & $19(9.2 \%) *:$ \\
\hline$S A B A$ & $1(0.1 \%)$ & $11(6.9 \%) *$ & $0(0.0 \%)$ \\
\hline$L A B A$ & $10(0.6 \%)$ & $60(37.5 \%) *$ & $17(8.3 \%) *$ \\
\hline$L A M A$ & $0(0.0 \%)$ & $0(0.0 \%)$ & $2(1.0 \%) *$ \\
\hline$S A M A$ & $0(0.0 \%)$ & $1(0.6 \%)$ & $0(0.0 \%)$ \\
\hline ICS & $16(0.9 \%)$ & $69(43.1 \%) *$ & $16(7.8 \%) *$ \\
\hline Leukotriene-receptor antagonist & $2(0.1 \%)$ & $20(12.5 \%) *$ & $0(0.0 \%)$ \\
\hline \multicolumn{4}{|l|}{ Other medication } \\
\hline Anti-histaminica (ATC R06) & $49(2.7 \%)$ & $27(16.9 \%) *$ & $4(1.9 \%)$ \\
\hline OCS (ATC H02) & $16(0.9 \%)$ & $1(0.6 \%)$ & $3(1.5 \%)$ \\
\hline
\end{tabular}

eGFR = estimated Glomerular Filtration Rate; SABA = short-acting beta-agonist; LABA = long-acting beta-agonist; LAMA = long-acting muscarinic antagonist; ICS = inhalation corticosteroids; OCS $=$ oral corticosteroids; ${ }^{*} p<0.05$ compared to control subjects. 


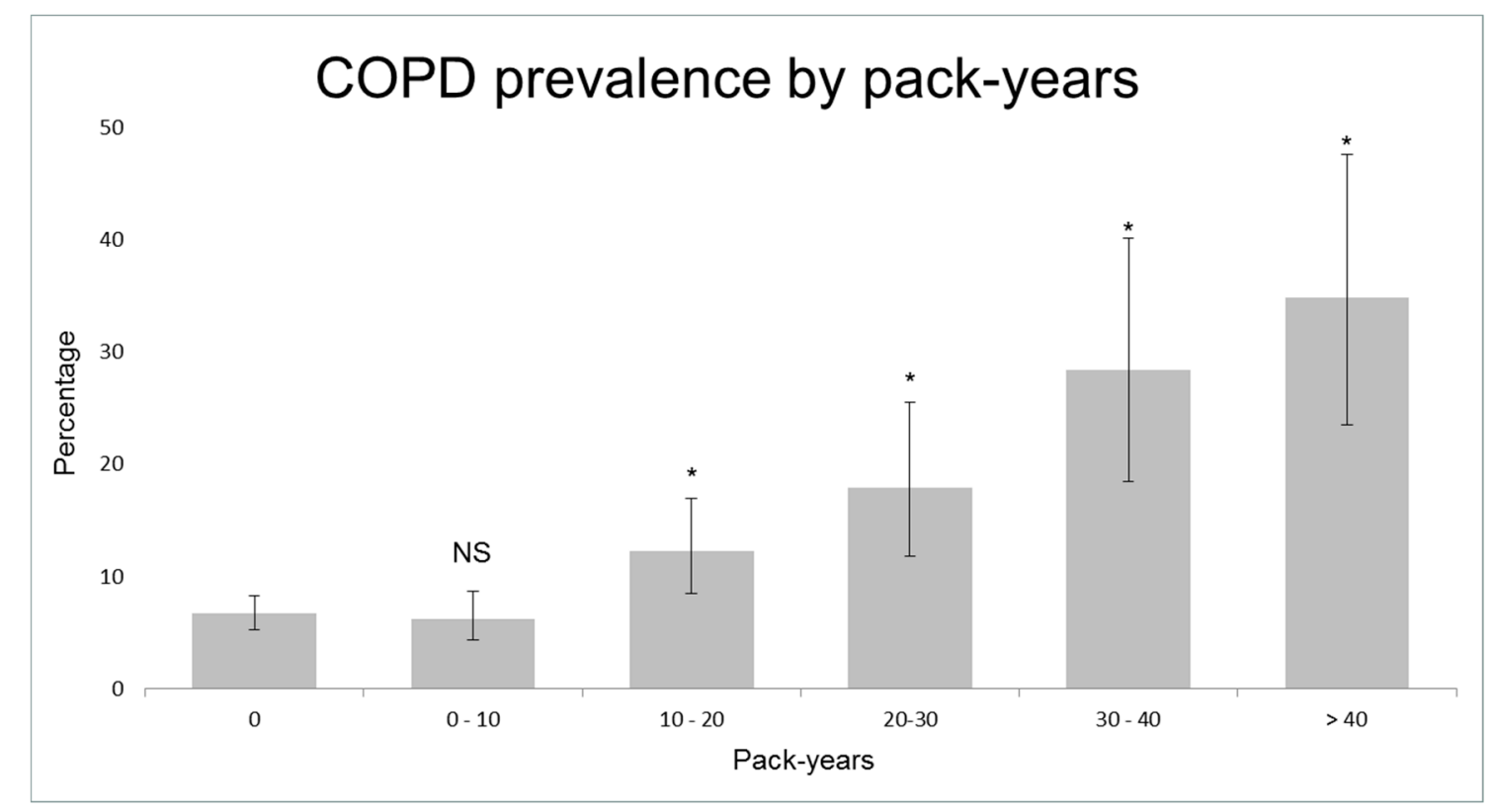

Figure 3. Prevalence of Chronic Obstructive Pulmonary Disease (COPD) according to pack-years. NS $=$ not significant; ${ }^{*}=p<0.05$ compared to subjects that have never smoked.

Within 2192 participants (98.7\%) with available blood eosinophil counts, the median absolute blood eosinophil count was higher in current asthma, ever asthma, clinical COPD and ACO subjects compared to controls, but less in sub-clinical COPD subjects (Table 2). In logistic regression analysis adjusted for age, sex, BMI, current smoking, type 2 diabetes and corticosteroid intake, eosinophil percentage was associated with current asthma (OR $=2.4,95 \% \mathrm{CI} 1.5-3.9)$, ever asthma (OR = 2.9, $95 \%$ CI 1.1-7.3) and clinical COPD (OR $=1.795 \%$ CI 1.1-2.7), but not with sub-clinical COPD (OR = 1.2, 95\%CI 0.7-1.9). The association between eosinophil percentage and ever asthma lost statistical significance when adjusted for atopy (OR $=2.4,95 \% \mathrm{CI} 0.9-6.2)$.

Table 2. Eosinophilic inflammation in subjects in the Asklepios Study.

\begin{tabular}{ccccccc}
\hline & Controls & Current Asthma & Ever Asthma & Sub-Clinical COPD & Clinical COPD & ACO \\
\hline $\begin{array}{c}\text { Eosinophil count } \\
(\text { cells } / \mu \mathrm{L})\end{array}$ & $130.0(80.0-200.0)$ & $160.0(110.0-250.0)^{*}$ & $170.0(110.0-230.0)$ & $140.0(90.0-210.0)^{* *}$ & $160.0(110.0-220.0)^{*}$ & $180.0(80.0-340.0)$ \\
$\quad \begin{array}{l}\text { Eosinophil count } \\
\text { ULN } / \geq 310(\%)\end{array}$ & $159(9.0 \%)$ & $23(17.2 \%)^{*}$ & $5(22.7 \%)^{*}$ & $11(10.8 \%)$ & $15(14.7 \%)$ \\
$\begin{array}{c}\text { Eosinophil percentage } \\
(\%)\end{array}$ & $2.0(1.3-3.0)$ & $2.4(1.6-3.8)^{*}$ & $2.3(1.8-5.4)$ & $2.2(1.4-3.3)$ & $2.3(1.6-3.5)^{*}$ & $2.4(1.3-5.0)$ \\
$\begin{array}{c}\text { Eosinophil percentage } \\
\text { ULN } / \geq 4.6,(\%)\end{array}$ & $165(9.3 \%)$ & $22(16.4 \%)^{*}$ & $6(27.3 \%)^{*}$ & $9(8.8 \%)$ & $19(18.6 \%)^{*}$ & $3(27.3 \%)^{*}$ \\
\hline
\end{tabular}

Comparison of median blood eosinophil count in cases versus controls; ACO = Asthma and COPD overlap; ULN $=$ upper limit of normal (90th percentile). ${ }^{*} p<0.05 .{ }^{* *} p<0.1$.

\section{Discussion}

In this cohort of middle-aged individuals in Belgium (mean age 56 years), the prevalence of asthma is $7.2 \%$, the prevalence of COPD is $9.3 \%$, and the prevalence of ACO is $0.5 \%$. We found an increased systemic eosinophilia in asthma cases, regardless of clinical remission, and in clinical-but not sub-clinical-COPD.

The prevalence estimates of asthma and COPD, in this study, are in line with previous findings. The literature on the epidemiology of asthma in middle-aged and older subjects is rising and their prevalence has been estimated between $5 \%$ and $14 \%$ [31]. The prevalence of COPD ranged between $2.6-26.1 \%$ in European adult populations over 40 years [4,5], yet COPD was often under-diagnosed and under-treated in this study, despite that these cases often reported respiratory symptoms. Therefore, more awareness of lung-function deterioration in middle-aged populations, and the adherence to clinical practice guidelines, is needed. 
Interestingly, we showed that the systemic eosinophil count is increased in asthma cases, despite clinical remission. Increased eosinophilic inflammation in asthma subjects, after clinical remission, has been observed [25,27,32-35], but prior studies consisted of small sample sizes and/or were conducted in hospital settings. This study of a more representative sample of the general population reinforced these preliminary findings. Although promising, further prospective research is needed to confirm whether the persistent increase of subjects' blood eosinophil count-as a proxy of persistent AHR-is also a predictor of asthma relapse. If so, it could potentially serve as a clinical decision directory for longer lasting maintenance therapy.

Clinical-but not sub-clinical-COPD was characterized by increased eosinophilic inflammation in this study. Only few studies researching COPD and blood eosinophilia, in a general population setting, were previously done [36-38]. The majority $(70.7 \%)$ of COPD cases in a US population exhibited eosinophil percentages of $>2 \%$ [37]. Danish COPD patients, with a baseline eosinophil count of $>340$ cells $/ \mu \mathrm{L}$, had a higher increased risk of severe exacerbations [36]. COPD patients from a UK study with eosinophil counts of $\geq 450$ cells/ $\mu \mathrm{L}$ during stable disease had a higher exacerbation rate during the following year [38]. Given the high intra-person variability of blood eosinophil count, multiple measures of systemic eosinophilia could possibly improve the accuracy of these predictions, which remains a challenge for future studies [39].

Despite the strong association between cigarette smoking and COPD, we found that a significant part of COPD subjects had a smoking history of less than 10 pack-years. The incidence of COPD in never-smokers indicates that other factors, such as genetic susceptibility, impaired lung growth, respiratory infections, and environmental exposures, including occupational exposures and (outdoor and indoor) air pollution, likely contribute to the development of COPD. Consistent with this study, three other population-based studies reported similar results: $16.3 \%$ of COPD subjects in the Netherlands had never smoked [40], 42.9\% of COPD subjects in European countries had smoked less than 20 pack-years [41], and more than half (59.6\%) of COPD subjects from a Korean population had smoked less than 100 cigarettes in their entire life [42]. Nevertheless, most randomized clinical trials, that examine the efficacy and safety of pharmacologic treatments for COPD, only include COPD patients with a history of cigarette smoking of at least 10 pack-years. However, treatment effects could differ in COPD subjects with different disease mechanisms.

This study has some limitations. First, the use of pre-bronchodilator spirometry does not enable distinctions to be drawn between asthma cases with current airflow obstruction and COPD or ACO. However, we carefully checked the subjects' medical records, and none of those classified as having COPD (based on presence of pulmonary obstruction) had a history of asthma. Nevertheless, misclassification remains possible when, for example, a diagnosis of asthma was wrongly missed by a GP. The relatively frequent occurrence of atopy, among COPD subjects with a smoking history of 10 pack-years or less, indicates the presence of such misclassification to some extent. Second, lung functions were measured at a single time-point using a fixed cut-off for FEV1/FVC; thus, there may have been some misclassification of obstructive pulmonary function, according to the current guidelines [43]. Third, 17 participants were ineligible to perform spirometry due to bad health (e.g., recent surgery, esophageal varices, difficult exhalation, nervousness), which could have resulted in under-representation of subjects with more severe asthma or COPD.

The main strengths of this study are its large sample size $(n=2221)$ and population-based nature. The application of exclusion criteria at baseline is an acknowledged risk for selection bias, and is likely to under-estimate the prevalence of COPD, since both COPD and cardiovascular diseases share a common ground, namely cigarette exposure. However, we believe that the results from this study are generalizable to other populations, given the small number of participants excluded, and given the similarities between this population and others (e.g. prevalence of asthma and COPD, and population characteristics). Adding to this, the loss of follow-up between round 1 and round 2 of the Asklepios study was minimal, with re-examination in $91 \%$ of individuals. The second strength is that all measurements were carried out in a standardized manner by the same investigator. Third, 
COPD diagnosis was strictly validated based on spirometry, and the asthma cases were validated using data from the subjects' medical files and questionnaire data. The completeness of the participants' medical information assumes that few diagnoses were missed. Fourth, the prevalence of asthma and COPD in Belgium has not been previously reported. Last, we distinguished clinical from sub-clinical asthma cases, thereby providing useful information on the characteristics of asthma subjects after clinical remission.

\section{Conclusions}

In summary, this study showed that, both asthma and COPD, are common diseases in the middle-aged population of the Asklepios study in Belgium, and that COPD is often under-diagnosed and under-treated, despite respiratory symptomatology. A greater awareness of lung-function deterioration in the middle-aged population, and adherence to clinical practice guidelines is needed. Interestingly, the systemic eosinophil count was increased in asthma cases, despite clinical remission. Future studies should focus on the utility of systemic eosinophil count to predict asthma relapse after clinical remission.

Supplementary Materials: The following are available online at http://www.mdpi.com/2077-0383/8/8/1122/s1, Figure S1: Estimated probability of COPD according to pack-years, Figure S2: Characteristics of cases with current asthma and clinical COPD, Table S1: Characteristics of COPD cases stratified by $>10$ pack-years and $\leq 10$ pack-years of smoking history.

Author Contributions: Conceptualization, G.G.B., L.L., and E.R.R.; methodology, S.R.A.W., L.L., M.L.D.B., and E.R.R.; software, E.R.R.; validation, S.R.A.W., L.L., and E.R.R.; formal analysis, S.R.A.W., L.L., and E.R.R.; investigation, S.R.A.W., L.L., G.G.B. and E.R.R.; resources, G.G.B. and E.R.R.; data curation, E.R.R.; writing-original draft preparation, S.R.A.W.; writing-review and editing, L.L., M.L.D.B., G.G.B., and E,R.; visualization, S.R.A.W.; supervision, L.L., G.G.B., and E.R.R.; project administration, E.R.R.; funding acquisition, E.R.R.

Funding: The Asklepios Study is supported by the Fund for Scientific Research-Flanders (FWO research grants G042703 and G083810N). This research was funded by the Fund for Scientific Research-Flanders (Fonds voor Wetenschappelijk Onderzoek Vlaanderen) grant number 3G037618. The funders had no role in the design of the study; in the collection, analyses, or interpretation of data; in the writing of the manuscript, or in the decision to publish the results.

Conflicts of Interest: The authors declare no conflict of interest related to this manuscript.

\section{Appendix A. Study Population and Baseline Data Collection}

The Asklepios study comprises 2524 subjects (1301 women) approximately 35 to 55 years of age at the baseline examination in 2002-2004 (round 1), with a complete re-examination of $91 \%$ of subjects after a median of 10.1 (9.8-10.8) years of follow-up (round 2: in 2011-2016). At the baseline investigation, subjects were apparently healthy subjects free from overt cardiovascular disease. The subjects were randomly sampled from two Belgian communities (Erpe-Mere and Nieuwerkerken) with approval of the ethics committee of Ghent University Hospital. These communities have a very active and organized participation of a group of 89 general practitioners (regional coverage for Erpe-Mere and Nieuwerkerken $>95 \%$ ). 8104 of the approximately 25,000 inhabitants were within the target age group (data provided by local authorities) and were randomly sampled from the population list through post mailing. Partners and relatives of those recruited by mailing were also eligible for study entry (if they inhabited Erpe-Mere or Nieuwerkerken) and a total of 703 subjects were recruited in this manner. Subjects were initially screened by their general practitioner (GP), who reviewed inclusion and exclusion criteria and provided a detailed personal medical history, conventional cardiovascular risk profile and an overview of drug use in the preceding 6 months before inclusion. Exclusion criteria at baseline were: 1 . clinical presence of atherosclerosis/atherothrombosis; 2 . major concomitant illness; 3. Diabetes mellitus (DM) type 1, and type 2 if proven macro-vasculopathy or significant renal impairment; 4 . conditions precluding accurate haemodynamic assessment (atrial fibrillation, pregnancy); 5 . inability to provide informed consent. Participants completed a study questionnaire, which was reviewed by the study nurse together with the subject during the participant examination. 
Measurements of round 2 [29] were performed during a continuous period, between 2011 and 2016 at the same single study site in Erpe-Mere and essentially mirrored all examinations performed in round 1 (informed consent, study questionnaire, basic clinical data, extensive blood sampling, echocardiographic examination, and vascular echographic and arterial tonometric measurements), with the addition of spirometry testing. In this study, we used measurements of round 2 (as no spirometry was performed in round 1 ).

\section{Appendix B. Dutch Translation of the Third European Community Respiratory Health Survey}

1. Hebt $\mathrm{u}$ op enig ogenblik in de laatste 12 maanden piepen of fluiten in uw borstkas gehad?

a. Was u kortademig wanneer dit piepend geluid aanwezig was?

b. Hebt $\mathrm{u}$ dit piepen of fluiten gehad wanneer $\mathrm{u}$ niet verkouden was?

2. Bent $\mathrm{u}$ op enig ogenblik in de laatste 12 maanden wakker geworden met een gevoel van beklemming in de borstkas?

3. Bent $\mathrm{u}$ op enig ogenblik in de laatste 12 maanden wakker geworden door een aanval van kortademigheid?

4. Heeft $\mathrm{u}$ op enig ogenblik in de laatste 12 maanden een aanval van kortademigheid gehad die begon na inspanning?

5. Heeft $\mathrm{u}$ op enig ogenblik in de laatste 12 maanden een aanval van kortademigheid gehad die overdag begon wanneer $\mathrm{u}$ in rust was?

6. Bent $\mathrm{u}$ op enig ogenblik in de laatste 12 maanden wakker geworden door een hoestbui?

7. Hoest $\mathrm{u}$ bijna dagelijks gedurende tenminste 3 maanden per jaar?

8. Hoest $\mathrm{u}$ bijna dagelijks gedurende tenminste 3 maanden per jaar fluimen o pvanuit uw borstkas?

9. Hebt $\mathrm{u}$ in de laatste $\mathbf{1 2}$ maanden een aanval van astma gehad?

10. Neemt $\mathrm{u}$ momenteel geneesmiddelen (bv. puffers, aerosols, tabletten) voor astma?

11. Hebt u enige vorm van neusallergie, "hooikoorts" inbegrepen?

a. Hoe oud was $\mathrm{u}$ toen $\mathrm{u}$ voor het eerst hoorkoort of neusallergie had?

12. Hebt $\mathrm{u}$ tot heden ooit astma gehad?

a. Werd dit door een arts bevestigd?

b. Hoe oud was $\mathrm{u}$ toen $\mathrm{u}$ voor het eerste een astma-aanval had?

13. Hebt u momenteel astma?

14. Has uw vader, moeder of één van uw broers of zusters ooit astma?

15. Rookte uw moeder ooit regelmatig tijdens uw kinderjaren of vooraleer $\mathrm{u}$ geboren was?

16. Rookte uw moeder wanneer ze van u zwanger was?

17. Hebt $\mathrm{u}$ voor de leeftijd van 5 jaar een ernstige long- of luchtweginfectie gehad?

18. Heeft een arts tegen $\mathrm{u}$ ooit gezegd dat $\mathrm{u}$ chronische bronchitis, COPD of emfyseem heeft?

a. Hoe oud was $\mathrm{u}$ toen een arts gezegd heeft dat $\mathrm{u}$ chronische bronchitis, COPD of emfyseem had?

19. Heeft $\mathrm{u}$ in de laatste 12 maanden regelmatig (d.w.z. op de meeste dagen) een corticosteroiden-inhalator (bv. pulmicort, becotide) gebruikt?

20. Heeft $\mathrm{u}$ ooit gedurende een jaar gerookt?

a. Hoe oud was $\mathrm{u}$ toen $\mathrm{u}$ startte met roken?

b. Heeft u gedurende de laatste maand gerookt? 
c. Hoe oud was $\mathrm{u}$ toen $\mathrm{u}$ voor het laatst rookte? (indien $\mathrm{u}$ nog steeds rookt, vul dan uw huidige leeftijd in)

21. Hoeveel jaar woont $\mathrm{u}$ reeds in $\mathrm{uw}$ huidige woning? Indien minder dan 12 maanden, vul dan $1 \mathrm{in}$.

\section{References}

1. Soriano, J.B. Global, regional, and national deaths, prevalence, disability-adjusted life years, and years lived with disability for chronic obstructive pulmonary disease and asthma, 1990-2015: A systematic analysis for the Global Burden of Disease Study 2015. Lancet Respir. Med. 2017, 5, 691-706. [CrossRef]

2. Vos, T. Global, regional, and national incidence, prevalence, and years lived with disability for 328 diseases and injuries for 195 countries, 1990-2016: A systematic analysis for the Global Burden of Disease Study 2016. Lancet 2017, 390, 1211-1259. [CrossRef]

3. Lozano, R.; Naghavi, M.; Foreman, K.; Lim, S.; Shibuya, K.; Aboyans, V.; Abraham, J.; Adair, T.; Aggarwal, R.; Ahn, S.Y.; et al. Global and regional mortality from 235 causes of death for 20 age groups in 1990 and 2010: A systematic analysis for the Global Burden of Disease Study 2010. Lancet 2012, 380, 2095-2128. [CrossRef]

4. Masoli, M.; Fabian, D.; Holt, S.; Beasley, R. Global Initiative for Asthma (GINA) Program The global burden of asthma: Executive summary of the GINA Dissemination Committee Report. Allergy 2004, 59, 469-478. [CrossRef]

5. Atsou, K.; Chouaid, C.; Hejblum, G. Variability of the chronic obstructive pulmonary disease key epidemiological data in Europe: Systematic review. BMC Med. 2011, 9, 7. [CrossRef]

6. Vos, T.; Barber, R.; Bertozzi-Villa, A.; Biryukov, S.; Bolliger, I.; Charlson, F.; Davis, A.; Degenhardt, L.; Dicker, D.; Duan, L.; et al. Global, regional, and national incidence, prevalence, and years lived with disability for 301 acute and chronic diseases and injuries in 188 countries, 1990-2013: A systematic analysis for the Global Burden of Disease Study 2013. Lancet 2015, 386, 743-800. [CrossRef]

7. Prince, M.J.; Wu, F.; Guo, Y.; Gutierrez Robledo, L.M.; O'Donnell, M.; Sullivan, R.; Yusuf, S. The burden of disease in older people and implications for health policy and practice. Lancet 2015, 385, 549-562. [CrossRef]

8. Herse, F.; Kiljander, T.; Lehtimaki, L. Annual costs of chronic obstructive pulmonary disease in Finland during 1996-2006 and a prediction model for 2007-2030. NPJ Prim. Care Respir. Med. 2015, 25, 15015. [CrossRef]

9. Muka, T.; Imo, D.; Jaspers, L.; Colpani, V.; Chaker, L.; van der Lee, S.J.; Mendis, S.; Chowdhury, R.; Bramer, W.M.; Falla, A.; et al. The global impact of non-communicable diseases on healthcare spending and national income: A systematic review. Eur. J. Epidemiol. 2015, 30, 251-277. [CrossRef]

10. Hanania, N.A.; King, M.J.; Braman, S.S.; Saltoun, C.; Wise, R.A.; Enright, P.; Falsey, A.R.; Mathur, S.K.; Ramsdell, J.W.; Rogers, L.; et al. Asthma in the elderly: Current understanding and future research needs-A report of a National Institute on Aging (NIA) workshop. J. Allergy Clin. Immunol. 2011, 128, 4-24. [CrossRef]

11. Edwards, M.R.; Saglani, S.; Schwarze, J.; Skevaki, C.; Smith, J.A.; Ainsworth, B.; Almond, M.; Andreakos, E.; Belvisi, M.G.; Chung, K.F.; et al. Addressing unmet needs in understanding asthma mechanisms: From the European Asthma Research and Innovation Partnership (EARIP) Work Package (WP)2 collaborators. Eur. Respir. J. 2017, 49, 1602448. [CrossRef]

12. Brusselle, G.; Germinaro, M.; Weiss, S.; Zangrilli, J. Reslizumab in patients with inadequately controlled late-onset asthma and elevated blood eosinophils. Pulm. Pharmacol. Ther. 2017, 43, 39-45. [CrossRef]

13. Ronmark, E.; Lindberg, A.; Watson, L.; Lundback, B. Outcome and severity of adult onset asthma-report from the obstructive lung disease in northern Sweden studies (OLIN). Respir. Med. 2007, 101, 2370-2377. [CrossRef]

14. Westerhof, G.A.; Coumou, H.; de Nijs, S.B.; Weersink, E.J.; Bel, E.H. Clinical predictors of remission and persistence of adult-onset asthma. J. Allergy Clin. Immunol. 2018, 141, 104-109. [CrossRef]

15. Kostikas, K.; Brindicci, C.; Patalano, F. Blood Eosinophils as Biomarkers to Drive Treatment Choices in Asthma and COPD. Curr. Drug Targets 2018, 19, 1882-1896. [CrossRef]

16. Brusselle, G.; Pavord, I.D.; Landis, S.; Pascoe, S.; Lettis, S.; Morjaria, N.; Barnes, N.; Hilton, E. Blood eosinophil levels as a biomarker in COPD. Respir. Med. 2018, 138, 21-31. [CrossRef]

17. Price, D.B.; Rigazio, A.; Campbell, J.D.; Bleecker, E.R.; Corrigan, C.J.; Thomas, M.; Wenzel, S.E.; Wilson, A.M.; Small, M.B.; Gopalan, G.; et al. Blood eosinophil count and prospective annual asthma disease burden: A UK cohort study. Lancet Respir. Med. 2015, 3, 849-858. [CrossRef] 
18. Casciano, J.; Krishnan, J.A.; Small, M.B.; Buck, P.O.; Gopalan, G.; Li, C.H.; Kemp, R.; Dotiwala, Z. Burden of asthma with elevated blood eosinophil levels. BMC Pulm. Med. 2016, 16, 100:1-100:7. [CrossRef]

19. Zeiger, R.S.; Schatz, M.; Dalal, A.A.; Chen, W.; Sadikova, E.; Suruki, R.Y.; Kawatkar, A.A.; Qian, L. Blood Eosinophil Count and Outcomes in Severe Uncontrolled Asthma: A Prospective Study. J. Allergy Clin. Immunol. Pract. 2017, 5, 144-153. [CrossRef]

20. Kerkhof, M.; Tran, T.N.; Soriano, J.B.; Golam, S.; Gibson, D.; Hillyer, E.V.; Price, D.B. Healthcare resource use and costs of severe, uncontrolled eosinophilic asthma in the UK general population. Thorax 2018, 73, 116-124. [CrossRef]

21. Makela, M.J.; Christensen, H.N.; Karlsson, A.; Rastogi, S.; Kettunen, K. Health care resource utilization and characteristics of patients with eosinophilic asthma in secondary health care in Finland. Eur. Clin. Respir. J. 2018, 5, 1458560:1-1458560:8. [CrossRef]

22. Kerkhof, M.; Tran, T.N.; van den Berge, M.; Brusselle, G.G.; Gopalan, G.; Jones, R.C.; Kocks, J.W.; Menzies-Gow, A.; Nuevo, J.; Pavord, I.D.; et al. Association between blood eosinophil count and risk of readmission for patients with asthma: Historical cohort study. PLoS ONE 2018, 13, 0201143. [CrossRef]

23. Emerman, C.L.; Cydulka, R.K. Factors Associated with Relapse after Emergency Department Treatment for Acute Asthma. Ann. Emerg. Med. 1995, 26, 6-11. [CrossRef]

24. Tran, T.N.; Khatry, D.B.; Ke, X.K.; Ward, C.K.; Gossage, D. High blood eosinophil count is associated with more frequent asthma attacks in asthma patients. Ann. Allergy Asthma Immunol. 2014, 113, 19-24. [CrossRef]

25. Boulet, L.P.; Turcotte, H.; Plante, S.; Chakir, J. Airway Function, Inflammation and Regulatory T Cell Function in Subjects in Asthma Remission. Can. Respir. J. 2012, 19, 19-25. [CrossRef]

26. Broekema, M.; Timens, W.; Vonk, J.M.; Volbeda, F.; Lodewijk, M.E.; Hylkema, M.N.; ten Hacken, N.H.T.; Postma, D.S. Persisting Remodeling and Less Airway Wall Eosinophil Activation in Complete Remission of Asthma. Am. J. Respir. Crit. Care Med. 2011, 183, 310-316. [CrossRef]

27. Wang, A.L.; Datta, S.; Weiss, S.T.; Tantisira, K.G. Remission of persistent childhood asthma: Early predictors of adult outcomes. J. Allergy Clin. Immunol. 2019, 143, 1752-1759. [CrossRef]

28. Fuchs, O.; Bahmer, T.; Rabe, K.F.; von Mutius, E. Asthma transition from childhood into adulthood. Lancet Respir. Med. 2017, 5, 224-234. [CrossRef]

29. Rietzschel, E.R.; De Buyzere, M.L.; Bekaert, S.; Segers, P.; De Bacquer, D.; Cooman, L.; Van Damme, P.; Cassiman, P.; Langlois, M.; van Oostveldt, P.; et al. Rationale, design, methods and baseline characteristics of the Asklepios Study. Eur. J. Cardiovasc. Prev. Rehabil. 2007, 14, 179-191. [CrossRef]

30. Quanjer, P.H.; Stanojevic, S.; Cole, T.J.; Baur, X.; Hall, G.L.; Culver, B.H.; Enright, P.L.; Hankinson, J.L.; Ip, M.S.; Zheng, J.; et al. Multi-ethnic reference values for spirometry for the 3-95-yr age range: The global lung function 2012 equations. Eur. Respir. J. 2012, 40, 1324-1343. [CrossRef]

31. De Roos, E.W.; Lahousse, L.; Verhamme, K.M.C.; Braunstahl, G.-J.; Ikram, M.A.; in 't Veen, J.C.C.M.; Stricker, B.H.C.H.; Brusselle, G.G.O. Asthma and its comorbidities in middle-aged and older adults; the Rotterdam Study. Respir. Med. 2018, 139, 6-12. [CrossRef]

32. Muranaka, M.; Suzuki, S.; Miyamoto, T.; Takeda, K.; Okumura, H. Bronchial reactivities to acetylcholine and IgE levels in asthmatic subjects after long-term remissions. J. Allergy Clin. Immunol. 1974, 54, 32-40. [CrossRef]

33. Van Den Toorn, L.M.; Overbeek, S.E.; De Jongste, J.C.; Leman, K.; Hoogsteden, H.C.; Prins, J.-B. Airway Inflammation Is Present during Clinical Remission of Atopic Asthma. Am. J. Respir. Crit. Care Med. 2001, 164, 2107-2113. [CrossRef]

34. Yoshikawa, T.; Kanazawa, H. Characteristics of young atopic adults with self-reported past wheeze and airway hyperresponsiveness. Allergol. Int. 2012, 61, 65-73. [CrossRef]

35. Koh, Y.Y.; Kang, H.; Nah, K.M.; Kim, C.K. Absence of association of peripheral blood eosinophilia or increased eosinophil cationic protein with bronchial hyperresponsiveness during asthma remission. Ann. Allergy Asthma Immunol. 2003, 91, 297-302. [CrossRef]

36. Vedel-Krogh, S.; Nielsen, S.F.; Lange, P.; Vestbo, J.; Nordestgaard, B.G. Blood Eosinophils and Exacerbations in Chronic Obstructive Pulmonary Disease. The Copenhagen General Population Study. Am. J. Respir. Crit. Care Med. 2016, 193, 965-974. [CrossRef]

37. DiSantostefano, R.L.; Hinds, D.; Van Le, H.; Barnes, N.C. Relationship between blood eosinophils and clinical characteristics in a cross-sectional study of a US population-based COPD cohort. Respir. Med. 2016, 112, 88-96. [CrossRef] 
38. Kerkhof, M.; Sonnappa, S.; Postma, D.S.; Brusselle, G.; Agusti, A.; Anzueto, A.; Jones, R.; Papi, A.; Pavord, I.; Pizzichini, E.; et al. Blood eosinophil count and exacerbation risk in patients with COPD. Eur. Respir. J. 2017, 50, 1700761:1-1700761:4. [CrossRef]

39. Schumann, D.M.; Tamm, M.; Kostikas, K.; Stolz, D. Stability of the blood eosinophilic phenotype in stable and exacerbated chronic obstructive pulmonary disease. Chest 2019. [CrossRef]

40. Terzikhan, N.; Verhamme, K.M.C.; Hofman, A.; Stricker, B.H.; Brusselle, G.G.; Lahousse, L. Prevalence and incidence of COPD in smokers and non-smokers: The Rotterdam Study. Eur. J. Epidemiol. 2016, 31, 785-792. [CrossRef]

41. Lamprecht, B.; McBurnie, M.A.; Vollmer, W.M.; Gudmundsson, G.; Welte, T.; Nizankowska-Mogilnicka, E.; Studnicka, M.; Bateman, E.; Anto, J.M.; Burney, P.; et al. COPD in never smokers: Results from the population-based burden of obstructive lung disease study. Chest 2011, 139, 752-763. [CrossRef]

42. Lee, S.H.; Hwang, E.D.; Lim, J.E.; Moon, S.; Kang, Y.A.; Jung, J.Y.; Park, M.S.; Kim, S.K.; Chang, J.; Kim, Y.S.; et al. The Risk Factors and Characteristics of COPD among Nonsmokers in Korea: An Analysis of KNHANES IV and V. Lung 2016, 194, 353-361. [CrossRef]

43. GOLD. Global Strategy for Prevention, Diagnosis and Management of COPD; Global Initiative for Chronic Obstructive Lung Disease: Fontana, CA, USA, 2019.

(C) 2019 by the authors. Licensee MDPI, Basel, Switzerland. This article is an open access article distributed under the terms and conditions of the Creative Commons Attribution (CC BY) license (http://creativecommons.org/licenses/by/4.0/). 